\title{
レーザー駆動XUV〜X線の時間分解分光応用
}

\author{
清水 俊彦 ${ }^{1}$ ，猿倉 信彦 ${ }^{1}$ ，中野秀俊 ${ }^{2}$ \\ ${ }^{1}$ 大阪大学レーザーエネルギー学研究センター（†565-0807 大阪府吹田市山田丘2-6) \\ ${ }^{2}$ 日本電信電話 (株) NTT物性科学基礎研究所 (テ243-0198 神奈川県厚木市森の里若宮3-1)
}

\section{Time-Resolved Spectroscopy Using XUV/X-Ray Pulses Driven by Laser Pulses}

\author{
Toshihiko SHIMIZU, ${ }^{1}$ Nobuhiko SARUKURA, ${ }^{1}$ and Hidetoshi NAKANO ${ }^{2}$ \\ ${ }^{1}$ Institute of Laser Engineering, Osaka University, 2-6 Yamadaoka, Suita, Osaka 565-0871 \\ ${ }^{2}$ NTT Basic Research Laboratories, Nippon Telegraph and Telephone Corporation, 3-1 Morinosato Wakamiya, Atsugi, Kanagawa 243-0198
}

(Received July 2, 2010)

\begin{abstract}
X-ray pulse generated by an intense femtosecond-laser-pulse is not only short in duration, but also synchronized to the femtosecond laser pulse. This point is extremely important in realizing pump-probe measurements combined with femtosecond laser pulse to observe the dynamic responses of optically excited materials. This article shows examples of picosecond time-resolved X-ray absorption fine structure (XAFS) measurements using femtosecond-laser plasma soft x-ray as a diagnostic probe, which were conducted by NTT Basic Research Laboratories. Also, the current status of developing zinc oxide $(\mathrm{ZnO})$ scintillator by Osaka University is described. Such a device is useful for adjusting timing and positioning of VUV/X-ray pulses in pump-probe experiments.
\end{abstract}

Key Words: X-ray spectroscopy, X-ray absorption fi ne structure, X-ray lasers, Scintillator, Pump-probe measurement

1. はじめに

実験室環境で比較的簡便に高強度レーザー光を利用し て極端紫外 (XUV: Extreme Ultraviolet) からX線領域の光 を得るための典型的な手法として, 高次高調波発生法と レーザープラズマX線発生法を掲げることができる，前 者はレーザーの性質をそのまま引き継いでおり，現在， 短波長領域でコヒーレント光を実現し得る唯一の手法で あると共に, 適切なフェムト秒レーザー光を用いた場合 にはアト秒領域に迫ることもできる特徵を持つ ${ }^{1,2)}$. 高 調波の発生法としては, ガス状の媒質を利用する手法 ${ }^{3)}$ と高密度プラズマ中の電子の相対論的運動を利用する手 法 ${ }^{4,5)}$ が存在する。これらに対し, 高強度フェムト秒 レーザー光を固体ターゲット等に照射したときにター ゲット表面近傍に生成される高密度プラズマは, インコ ヒーレント光源ではあるが, 数十 $\mathrm{eV} ら 10 \mathrm{keV}$ 以上ま での広いエネルギー領域をカバーするテーブルトップサ イズの高輝度超短パルスX線源として利用できる ${ }^{6,7)}$. フェムト秒レーザーから得られるX線パルスはパルス幅 が狭いのみならず, レーザーパルスと自動的に高精度同 期している。 この性質は，レーザー励起によらない他の 高輝度X線源 (シンクロトロン軌道放射光, X線自由電子 レーザーなど)が備えていない著しい利点であり，フェ
ムト秒レーザーパルスとの組み合わせによる高時間分解 能のポンププローブ分光を容易に実現可能にすると期待 される。例えば, シンクロトロン軌道放射光からレー ザー光と同期した短パルスを得るためには, 電子ビーム をレーザーパルスでスライスする ${ }^{8)}$ な゙の特別な措置が 必要である。この観点から, フェムト秒レーザー励起X 線光源, 特にレーザー生成プラズマX線源を用いた時間 分解X 線回折 ${ }^{9-16)}$, 時間分解吸収分光 ${ }^{17-31)}$, 高次高調波を 用いた時間分解光電子分光 ${ }^{32-36,49-51)}$ などが精力的に研究 され始めている(Table 1). また, 最近では, シンクロト ロン軌道放射光施設で，電子ビームをレーザーパルスで スライスすることによって大光量のX線パルスを実現 し，これを時間分解X線回折などに応用する報告も増え てきている. Table 1に示した中で, 時間分解光電子分光 実現例の一部，特にアト秒時間分解計測に関連する実現 例は，レーザー支援光電効果を観測しており，時間分解 $\mathrm{X}$ 線回折あるいは時間分解X線吸収分光実現例とは異 なった状況を観測している．X線回折は結晶における原 子配置, 分子構造を直接与えるため, これまでに多くの 時間分解X線回折実験の結果が報告されている。これに 対して，X線吸収スペクトルからは，特定元素周辺の局 所配置, 電子準位, 化学結合状態などの詳細情報を抽出 することができる。中でも, EXAFS (Extended X-ray Ab- 
Table 1 Examples of material dynamics probed with femtosecond-laser-generated X-ray pulses.

\begin{tabular}{|c|c|c|c|}
\hline & Diffraction & Absorption Spectroscopy & Photoelectron spectroscopy \\
\hline Source & $\begin{array}{l}\text { Monochromatic hard } \mathrm{x} \text {-ray } \\
\left(\mathrm{K}_{\alpha}\right) \text { pulse }\end{array}$ & $\begin{array}{l}\text { Pulse with broadband contin- } \\
\text { uum spectrum } \\
\text { or } \\
\text { Continuously tunable pulse }\end{array}$ & (Quasi) Monochromatic pulse \\
\hline Features & $\begin{array}{l}\text { Probe ultrafast } \\
\text { structural } \\
\text { changes induced by laser } \\
\text { irradiation }\end{array}$ & $\begin{array}{l}\text { Probe ultrafast changes in } \\
\text { electronic structures, chemical } \\
\text { bonds, and local arrangements } \\
\text { of atoms induced by laser irra- } \\
\text { diation }\end{array}$ & $\begin{array}{l}\text { Probe ultrafast changes in elec- } \\
\text { tronic structures induced by } \\
\text { laser irradiation } \\
\text { Surface sensitive }(5-75 \AA ̊)\end{array}$ \\
\hline $\begin{array}{l}\text { Examples } \\
\text { (demonstrated) }\end{array}$ & $\begin{array}{l}\text { - Destruction } \\
\text { - Nonthermal melting } \\
\text { - Shockwave propagation } \\
\text { - Coherent phonon }\end{array}$ & $\begin{array}{l}\text { - Molecular dissociation } \\
\text { - Diagnosis of dense plasma } \\
\text { - Change in band structure of - } \\
\text { highly excited semiconduc- } \\
\text { tor } \\
\text { - Coherent phonon }\end{array}$ & $\begin{array}{l}\text { Dissociation processes in } \\
\text { molecules } \\
\text { Surface chemical reactions } \\
\text { Dynamics of core-electrons }\end{array}$ \\
\hline
\end{tabular}

sorption Fine Structure：広域X線吸収微細構造)は, X線 回折法とは相補的な計測手法であり，非晶質相や液相を 含む幅広い物質の局所構造(原子配置など)を決定する手 法として知られ, 高輝度X線光源の開発に伴って広く用 いられるようになっている ${ }^{53,54)}$ 。通常の時間分解レー ザー分光によって直接観測されるものは価電子のダイナ ミクスであり，物質構造に関わる情報を直接には得られ ない，これに対し，X線分光は，原子の特性を反映する 内殼電子に関連した情報, 物質構造情報を与えてくれ る。そのため, 短パルスX線をプローブとして利用すれ ば，特定原子に着目した時間分解分光が実現でき, 超短 パルスレーザー光電界によって誘起される構造相転移な どの動的過程における原子配置, 電子エネルギー構造な どの高速変化を直接測定することが可能となるであろ う。こうした観点から, 短パルスX線による時間分解X 線吸収分光が関心を集めつつある。また，X線で励起さ れる内殼電子のダイナミクスを計測するような新たな分 光への展開も期待される ${ }^{36)}$.

軟X線レーザーあるいは, レーザー光の高次高調波の ように, コヒーレンスを有するX線光源の場合には, そ の出力光の有する可干渉性を活用した時間分解スペック ル計測に基づく物質の微小領域での状態変化追跡などへ の応用が試みられている。例えば, 原子力機構の軟X線 レーザー ${ }^{37,38)}$ を利用した時間分解スペックル計測 ${ }^{39)} に$ よって $\mathrm{BaTiO}_{3}$ の相転移温度付近での分極クラスターなら びに $100 \mathrm{ps}$ 程度の時間領域で生じるドメイン構造摇らぎ が観測されている ${ }^{40)}$ 。さらに，X線自由電子レーザー (XFEL; X-ray Free Electron Laser)のように非常に高いX 線強度を実現可能な光源の登場は, X線領域での様々な 高強度現象を追求可能にすると期待される。実際, SPring-8に建設されたプロトタイプ機41)を利用して, 分 子の解離 ${ }^{42-45)}$, 原子.クラスターのイオン化 ${ }^{46,47)}, \mathrm{XUV}$ 域での過飽和吸収 ${ }^{48)}$ などの観測が実現され，新たな高強 度光科学研究の領域が開拓され始めている。軟X線レー ザーならびにX線自由電子レーザーに関して，本特集号 にそれぞれ解説論文が掲載されているので，それらの応
用研究に関する詳細は各々の論文を参照して頂きたい.

以上に述べたように，レーザー励起X線，X線レー ザーを利用した種々の時間分解分光・計測の実現が期待 されるが，こうした実験・計測を遂行する上で，光学調 整あるいはX線信号検出のために高効率, 高速, 大面積 のシンチレーターが有用な道具となる. すなわち, ポン ププローブ型の時間分解計測を行うためには, 計測対象 となる試料中でポンプパルスとプローブパルスとが空間 的に一致している必要がある。ささらに, 時間原点を決定 するためには，時間的にも2つのパルスを試料の位置で 重ね合わせることが要請される。高効率, 高速, 大面積 のシンチレーターは, このような要請を満たすための光 学調整を高い信頼性で実現するための実時間モニタとし ても有用である。また, 高効率, 高速シンチレーター は, 空間発展を伴う現象の時間分解計測における2次元 検出器としての応用も期待される.

本稿においては，まず，レーザーパルスとレーザープ ラズマX線パルスとの組み合わせによる時間分解分光の 実現例として, NTT物性科学基礎研究所のグループによ るフェムト秒レーザー光ポンプ，X線プローブの時間分 解吸収分光を中心に，これまでに実証された実験例を簡 単に紹介する。次に, 高効率, 高速, 大面積のシンチ レーター実現に向けた大阪大学レーザーエネルギー学研 究センターのグループによる取り組みを紹介しょう.

\section{2. ポンププローブ法による時間分解軟X線吸収分光}

冒頭で述べたようにレーザーパルスと同期したX線 パルスをプローブとして用いれば，レーザーパルス照射 が誘導する物質の構造・状態変化の時間発展が計測可能 になる，本章以降では，レーザー光ポンプ，X線プロー ブの時間分解吸収分光 (XAFS: X-ray Absorption Fine Structureなど)の実現例を紹介したい.

レーザー生成プラズマからのX線パルスをX線吸収分 光に適用する試みは，1980年代から散見され ${ }^{55-57) ， レ ー ~}$ ザーアブレーション過程58)，レーザー衝撃過程59)，レー 
ザープラズマの時間発展 ${ }^{60,61)}$ などがナノ秒時間分解能で 計測された。高強度フェムト秒レーザーの登場によって テーブルトップサイズで実現可能となったフェムト秒 レーザー生成プラズマからのピコ秒X線パルスを用い, 時間分解XAFSによって $\mathrm{SF}_{6}$ の光解離を観測する試み ${ }^{18)}$ が 超高速時間分解XAFSの先駆的研究である。その後, フェムト秒レーザープラズマX線をプローブとした時間 分解X線吸収分光によって, 高密度レーザー生成プラズ マの時間発展 ${ }^{19,62,63)}$, 半導体 $\left(\mathrm{Si}^{20,21)}, \mathrm{GaAs}^{64)}\right)$ の電子状態 変化, 金属錯体の光励起過程 ${ }^{24,65)}$ などが計測されてい る。また，レーザープラズマX線プローブによるサブナ ノ秒時間分解EXAFSとしては, 超大型レーザー装置を 利用したレーザー圧縮による $\mathrm{Fe} ， \mathrm{~V} ， \mathrm{Ti}$ の構造相転移観 測が報告されている ${ }^{66-68)}$ 。 なお, シンクロトロン軌道放 射光とフェムト秒レーザーとの同期技術, 超高速X線ス トリークカメラなどの開拓により, シンクロトロン軌道 放射光をプローブとして，金属錯体の光励起過程 ${ }^{65,69)}$, $\mathrm{Si}$ の光融解過程 ${ }^{70)}$ などが100 ps以下の時間分解能で観測 されるようになって, ポンププローブ法による時間分解 X線吸収分光への関心が高まっている，最近では，20 fs 程度の高次高調波を利用したEXAFSによる $\mathrm{Si}$ のコーレ ントフォノン観測も報告されている ${ }^{28,29)}$.

半導体産業への応用を目的として, レーザー溶融現象 が研究されてきた。その物理的機構を調べるために，従 来は, 超短パルスレーザー光の反射や表面 $\mathrm{SHG}$ (第二高 調波発生)を用いた時間分解計測が利用されてきた ${ }^{71}$. 近年, レーザー溶融過程の時間分解X線回折計測が行わ れ72), 結晶秩序が急速に失われる過程が直接的な手法で 計測されている。 これに対して, 時間分解XAFS法は溶 融状態の局所構造の情報をも計測できる ${ }^{58)}$. NTT物性科 学基礎研究所のグループは, これら先駆的な研究では計 測が困難であった $\mathrm{Si}$ のL吸収端EXAFSに着目し，ピコ秒 の時間分解能を有する計測を試み, レーザー溶融状態に おける原子間距離などの時間分解計測を実現した。同グ ループは，パルス幅100 fs，パルスエネルギー50 mJの出 力を繰り返し10 Hzで与えるTi:Sapphireレーザーを種に し，原子番号の大きな材料をターゲットとして生成され るプラズマから広帯域軟X線を発生させて ${ }^{73,74)}$, 時間分 解EXAFS計測システムを構築した。この結果 (Fig. 1) は, フェムト秒レーザー生成軟X線をプローブとする時 間分解EXAFS計測法が, フェムト秒レーザーパルスを 照射された物質の原子配置変化追跡に有効であることの 典型例である ${ }^{25)}$.

また, レーザープラズマX線源を用いた時間分解 XAFS計測システムと軟X線顕微鏡光学系を融合するこ とによって，レーザー照射された試料の状態変化の時間 発展のみならず, 空間分布発展も同時計測可能な分光シ ステムを構築することができる。このようなシステムの 典型的な応用が, レーザーアブレーションプルームの時 空間発展計測 ${ }^{26,27)}$ である。フェムト秒レーザーアブレー ションは, 微細加工の他にもナノ粒子生成 ${ }^{75,76)}$, 新規物 質合成 ${ }^{77-79)}$ などでも有用な過程として着目されている。

こうした工学的な応用における制御性を高めるために
は, フェムト秒レーザー光が物質表面に照射された瞬間 から，アブレーションプルームの放出，膨張に関わる動 的過程を詳細に把握することが重要である。アブレー ション初期過程へのアプローチ手法として, 時空間分解 XAFS法を採用する試みは，点集光したプローブX線を 利用して走查型配置 ${ }^{80,81)}$ ，もしくは単純な投影配置 ${ }^{63)}$ で 実施されてきた。これらに対して，図示したシステム (Fig. 2)では, 臨界照明の拡大結像光学系を構成するこ とによって, 点光源からほぼ等方的に放射されるX線の 利用効率を向上し，かつ試料面内での空間分布を同時計 測することによって計測に要する時間を短縮できるよう 工夫されている。テープターゲット表面に生成されたプ ラズマが軟X線源として利用され，プラズマから放射さ れる軟X線は，回転楕円体面鏡にて試料面上に集光され る.このときの集光スポット $(200 \mu \mathrm{m})$ が本システム

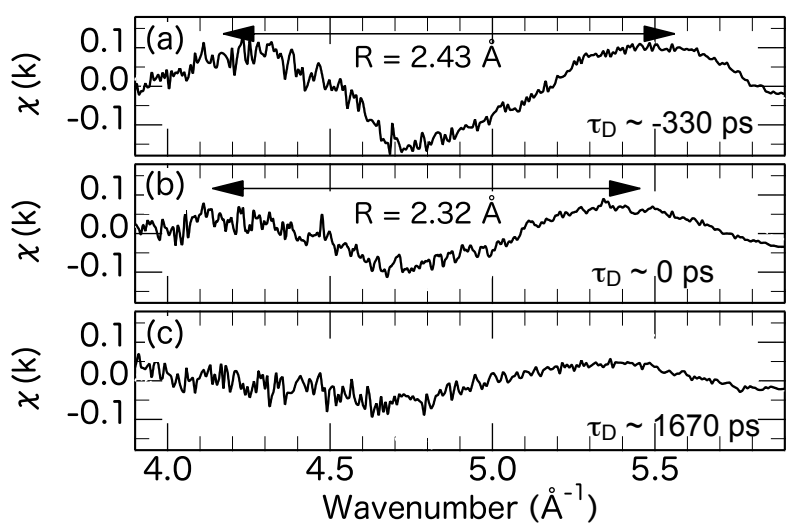

Fig. 1 Transient EXAFS spectra at various time delays. The spectrum (a) was obtained where the $\mathrm{x}$-ray pulse passed through the Si sample 330 ps before the arrival of the laser pulse. As shown in (b), the oscillation amplitude decreases with a small peak shift to a lower wave number when the x-ray pulse almost overlapped the laser pulse. The spectrum (c) shows that $1670 \mathrm{ps}$ after the arrival of the laser pulse, the EXAFS becomes too weak to analyze.

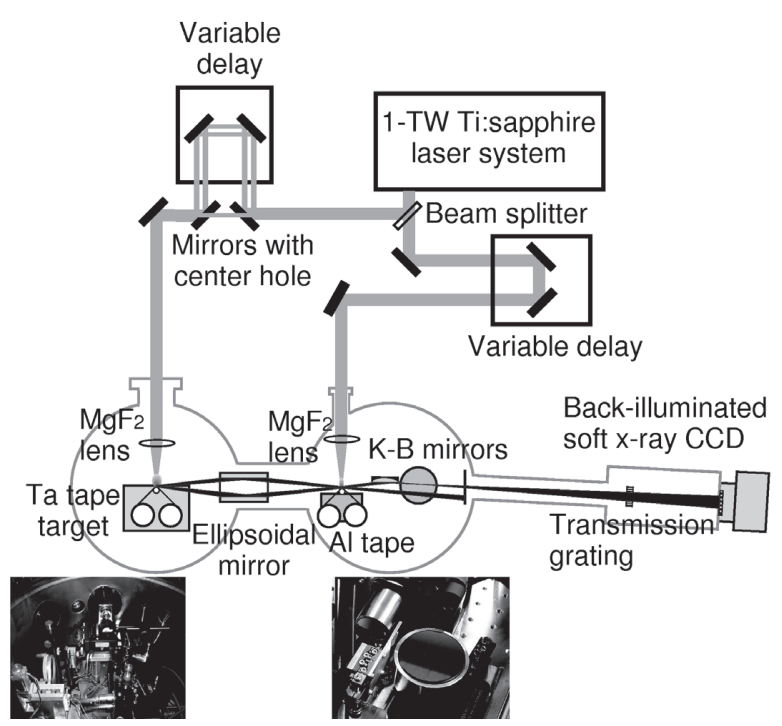

Fig. 2 Setup for spatiotemporally-resolved x-ray absorption spectroscopy. 
における空間的な視野となる。試料を通過した軟X線は 2枚の球面鏡を用いたKirkpatrick-Baez型配置(K-B配置) の結像光学系によって2次元検出器面上に導かれる. 本 システムでの試料面から検出器への拡大率は, 10倍であ る。この途中に，スリットと透過型回折格子を組み合わ せて軟X線光軸上に挿入することにより，スリットの長 手方向には空間情報を保持したまま, それと直交する方 向にスペクトル情報が得られる (Fig. 3)。この実験系で は，スリットの長手方向がレーザーアブレーション粒子 の噴出方向に一致するように設定されている．NTTのグ ループは，こうした時間空間分解XAFSシステムを利用 して, Fig. 3のように得られる時間空間分解吸光度スぺ クトル画像を解析することによって, フェムト秒レー ザーアブレーション粒子の同定, 拡散速度ならびに温度 の時間発展などの詳細情報取得に成功している。同グ ループによる時間分解XAFSの詳細に関しては, 既に 「レーザー研究」37巻12 号 ${ }^{82}$ などに詳しく紹介されている ので, そちらを参照して頂きたい.

見方を変え, 時間分解分光の対象として, レーザー照 射によって瞬時に変化する現象を選べば，X線パルス幅
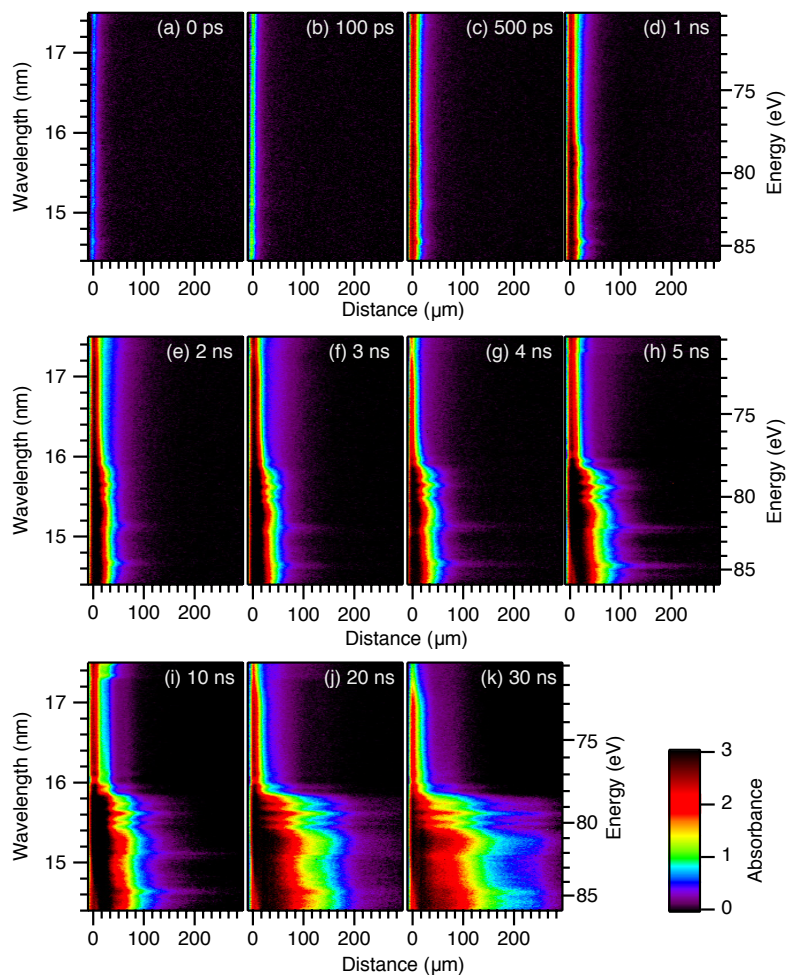

Fig. 3 Temporal sequence from 0 to $30 \mathrm{~ns}$ of spectrally resolved soft $x$-ray absorbance images in the $71-86 \mathrm{eV}$ energy region of an aluminum plume that was induced by a laser irradiation with an intensity of $4.2 \times 10^{14} \mathrm{~W} / \mathrm{cm}^{2}$ (a-k). Each image shows the absorbance spectrum of the aluminum plume as a function of the distance from the aluminum tape surface that corresponds to the distance of $0 \mu \mathrm{m}$. An absorbance, $\mu_{d}$, is defined as $\mu_{d}=\ln \left(I_{0} / I\right)$, where $I_{0}$ and $I$ are the reference soft x-ray flux without the plume absorption and the soft $\mathrm{x}$-ray flux transmitted through the plume, respectively. Each image consists of 3000 shots.
の評価が可能である，例えば，光電界イオン化過程では レーザー電界によるイオン化が瞬時に進行するので, レーザー電界が印加されている状況下で中性原子, イオ ンの数が大きく変化する。 これに着目すると，レーザー パルスとX線パルスの相互相関が実現され，X線のパル ス幅を推定できる ${ }^{17,90-93)}$.

\section{3. 酸化亜鉛シンチレーターの開発}

大阪大学レーザーエネルギー学研究センターでは, $\mathrm{XUV} / \mathrm{X}$ 線レーザーの応用に向けて, 酸化亜鉛 $(\mathrm{ZnO})$ シン チレーターの開発を行っている。短波長領域の新しいシ ンチレーターがEUVリソグラフィやポンププローブ研 究といった様々な応用に必要とされている。優秀なシン チレーターに求められる条件は高輝度であることと, 高 い空間分解能と時間分解能を持つことである. $\mathrm{ZnO}$ はそ の光学特性を改良することによって新たな発光ダイオー ドやナノ構造材料となることが期待されてきた物質であ る. $\mathrm{ZnO}$ 結晶は発光効率が高く, 水熱合成法という新し い手法により大口径で高品質なものの作製が可能となっ たため ${ }^{94)}$ ，XUV領域のシンチレーターとして大きな期 待を集めている. 発光波長も $380 \mathrm{~nm} ゙$ あ, 真空装置 が必要となる軟X線を $\mathrm{ZnO}$ を年て通常の大気中で扱え る波長に変換できることも重要である。また最近の研究 で金属イオンをドープすることで発光寿命を極めて短く できることもわかっている.

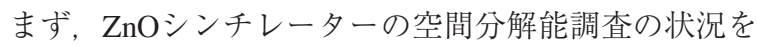
報告する. EUVリソグラフィのような応用においては, XUV光に対して分解能がどれくらいとれるかが肝要で ある。大阪大学のグループはかねてより関西原研の波長 $13.9 \mathrm{~nm}$ の軟X線レーザー ${ }^{37}$ 使用により，その特性評価を 行ってきた ${ }^{95)}$. その測定で数ns程度の短い発光寿命を持 つことを明らかにした。軟X線レーザーを初めとする光 源を使用する上でスポットサイズ計測は重要である。通 常，その測定にはナイフエッジ法等が用いられる。しか し, その測定にはショットを何度も繰り返す必要があ り, シングルショットでのスポットサイズ計測が必要と されている。そこで, このZnOシンチレーターを使用し 空間イメージング手法を用いてビームのスポットサイズ 計測を試みた ${ }^{96)}$. Fig. 4に結果を示す。軟X線レーザーは 焦点距離 $50 \mathrm{~cm}$ の球面鏡を用いて集光された. そして シュバルッシルト光学系により集光像をCCD面に拡大 した。この系の空間分解能は事前にUSAFテストター ゲットにより調べてあり, マイクロメートルのオーダー で計測が可能である。実際のスポット像を解析すると, そのサイズは横 $42 \mu \mathrm{m}$, 縦 $23 \mu \mathrm{m}$ であった，球面鏡の焦 点距離がそれほど短くないことを考慮すると, リーズナ ブルな值であると考えられる。この測定はシングル ショットで成されており, 効率的なスポットサイズ計測 の可能性を示した。現在, 軟X線レーザーのより細かい 集光をゾーンプレートで行い, $\mathrm{ZnO}$ シンチレーターの空 間分解能の限界調査に取り組んでいる。場合によっては 励起子の空間拡散といった現象も観測できることが期待 
(a)

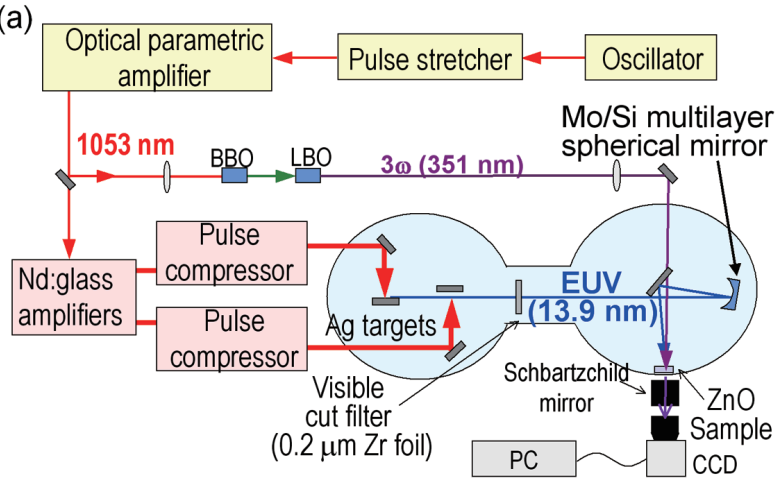

(b)

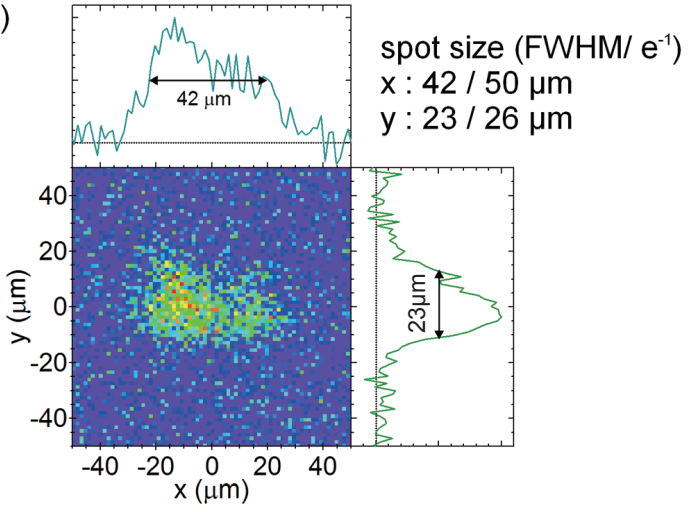

Fig. 4 Single-shot focal spot image of EUV laser obtained by using a $\mathrm{ZnO}$ scintillator. (a) experimental setup. (b) observed spot image.

できる。

次に時間分解能の向上について報告する。時間分解能 が必要とされる応用研究には, 将来タンパク質等の構造 解析や原子・電子のダイナミクスを追うことが可能とな るであろうXFELによるポンププローブ実験がある，先 の実験でナノ秒の発光寿命を持つことが示されたが, XFELのようなパルス幅のより短い光源に使用するには これでもまだ不十分である. 今回大阪大学のグループ は，これを改善するために鉄イオンを生成段階でドープ することにより発光の短寿命化に成功した。この $\mathrm{ZnO}$ 結 晶がFEL光源のシンチレーターとして使用できるかを確 かめるために, 現在SPring-8にて建設が進められている XFELのSCSS (SPring-8 Compact Selfamplified spontaneous emission Source) 試験加速器 ${ }^{411}$ を使用し発光特性を測定し た.アアライメンはNd:YAGレーザーの3次高調波を使 用している. SCSS試験加速器の波長は51 nm， $56 \mathrm{nm,}$ $61 \mathrm{~nm}$ のれぞれに設定した。 パルス幅は $200 \mathrm{fs}$ ，エネル

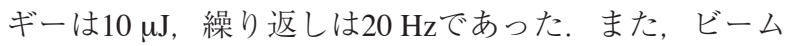
は斜入射凹面鏡により集光されて抢り ${ }^{97)}$ ， サンプルを設 置した焦点より $5 \mathrm{~cm}$ 離れた位置でのスポットサイズは招 よそ500 $\mu \mathrm{m}$ であった。 発光は石英レンズにより分光器 (回折格子600 本 $/ \mathrm{mm}$ ) のスリットに集められ波長分解さ れる。 そして分光器に接続したストリークカメラ (HAMAMATSU C1587) で寿命が測定された。 Fig. 3中の 測定結果は $56 \mathrm{~nm}$ 励起によるZnO結晶よりの発光を50000 ショット積算したものである. $56 \mathrm{~nm}$ 励起, $61 \mathrm{~nm}$ 励起 でも同様の測定を行い, 励起波長による違いが無いこと が分かった。 今回測定された発光寿命は高速成分で
$70 \mathrm{ps}$ ，低速成分で220 psであった ⿸ $^{98)}$ XUVシンチレー ターとしては極めて高速な寿命を持っていることが示さ れた。この測定で分かるように寿命が速く，波長依存性 もないZnO結晶はXUVシンチレーターとしてとても期待 できるものあるといえる。

より高速な発光の立ち上がりと減衰を持ったシンチ レーターを開発することができれば，ポンプ光とプロー ブ光のタイミング合わせ等も効率的にできるようにな り，限られたマシンタイムの節約にもなる。 そこで次 に，XFELを使用したポンププローブの実験のための準 備として, SCSS試験加速器とそれと同期したフェムト 秒レーザーのビーム間の相互ジッ夕をこの鉄ドープ $\mathrm{ZnO}$ シンチレーターを使用し計測した ${ }^{99)}$. 計測における注意 点として, 装置の電気的なジッタが測定結果に載らない ようにしなければならない. 発光寿命の測定では, 50000ショットもの重ねあわせであり立ち上がり部分が 特に広がってしまっている。シングルショットでの測定 では原理的にこの電気的なジッ夕は現れない，そこでシ ングルショットベースの測定のため, 分光器を通さない ことで信号強度を上げることを試みた，さらに，時間分 解能を向上させるためにストリークカメラもフェムト秒 領域まで測定できるもの(HAMAMATSU, FESCA200)を 使用した。また，ポンププローブ実験を想定して，試験 加速器と同期したフェムト秒Ti:Sapphireレーザー(波長 $800 \mathrm{~nm}$ ，パルス幅 $30 \mathrm{fs,}$ 繰り返し $1 \mathrm{kHz}$ )を同時に入射し た.レーザーの同期はCOHERENT社のSynchrolock-APに て行っている(Fig. 5). Fig. 5 (a) に測定された結果を示

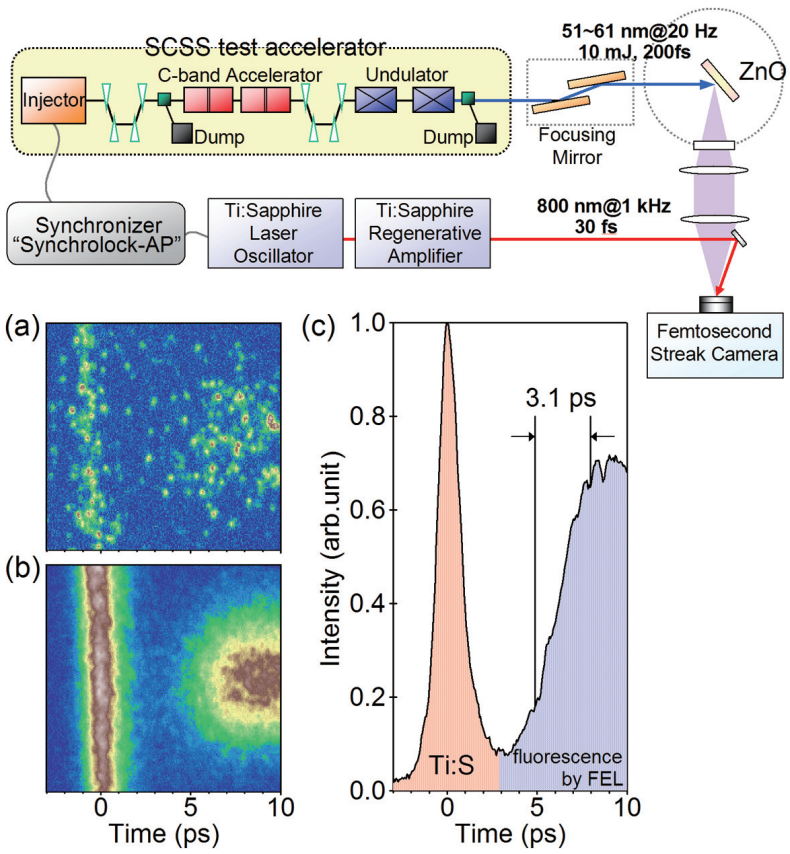

Fig. 5 Experimental setup in synchronization measurement of EUV-FEL and Ti:Sapphire laser (upper figure) and result of that (lower figure). (a) Single shot image captured by a streak camera. (b) 200 single shot images summed up to improve the signal-tonoise ratio. (c) temporal profile of (b) showing the fluorescence rise and decay times. 
す．S/N的に立ち上がり時間を正確に出すのはやや難し い状態ではあるものの, 信号強度が増加したためシング ルショットでもストリーク像が測定できた. S/Nを向上 させるには積算が有効である。先の電気的ジッタが現れ ないように，Ti:Sapphireレーザーの像を時間の基準と し, シングルショット像を何回か取ってそれを時間原点 とした後に改めて積算した。 Ti:Sapphireレーザーは時間 分解能(スリット幅程度で1〜2 ps) よりも充分に短い. そのようにして200ショット分を積算したものがFig. 5 (b)である。これの時間プロファイルをとったものが Fig. 5 (c)であり，立ち上がり時間は3.1 psであった。同 期レーザーと試験加速器の相互ジッタ(二つのレーザー の同期タイミングのずれ)はこの信号の立ち上がり時間 に含まれている。発光自体の立ち上がりもある程度の時 間があるとは推測されるが，この数值は相互ジッタの上 限と言え，それが3.1 psということである. ポンププ ローブ実験を行う上で二つのビームを精密に同期させる ことは重要であり, その同期の状況を詳しくモニターす ることが必要となる。この $\mathrm{ZnOシンチレーターはまさに}$ そういった目的に使用可能であるといえる。

\section{4. まとめ}

フェムト秒レーザー生成プラズマが広い波長領域をカ バーする超短パルスX線源であり，こうして得られるX 線パルスがレーザーパルスと同期している特徵を活か し，ポンププローブ法による時間分解X線吸収分光への 応用例を紹介した。さらに，ポンププローブ実験で必要 となるXUV〜X線を含む2ビームを時間空間ともに精密 に合わせてゆくためのモ二タ, あるいは高速検出器とし てのシンチレーター材料の開発状況も紹介した。

本稿では, NTT物性科学基礎研究所が取り組んできた フェムト秒レーザープラズマ軟X線をプローブとする時 間分解吸収分光の紹介を行ったが，時間分解能はピコ秒 程度に制限される。一方, 希ガス中での高次高調波発生 において，レーザー入射条件などを適切に設定すると， 極短紫外〜軟X線領域で疑似連続スペクトル ${ }^{100,101)}$ ， ある いは，連続波長可変 ${ }^{102,103)}$ の高調波が得られると報告さ れている。このような超短パルスをプローブ光とすれ ば，本稿で紹介した現象をフェムト秒時間分解能で計測 することも可能であろう ${ }^{28,29)}$. また, 高次高調波が超短 パルス性と共に高いコヒーレンスを有するという特徴 は, 時間分解の干涉計測において威力を発揮するであろ う。例えば，高い時間コヒーレンスの活用法として，一 定の遅延量を与えた 2 連パルス間の干渉スペクトル変化 を用いて，フェムト秒レーザー光による高密度プラズマ 生成ならびにその拡散過程をフェムト秒時間分解能で観 測することなどが実証されている

フェムト秒レーザーをベースとした超短パルスX線源 は今後, X線光学技術, X線計測・検出技術の進展と相 俟って, 原子スケール, フェムト〜ピコ秒の時間分解能 で物質応答の詳細な機構に迫ることを可能にし, ナノテ クノロジー, バイオテクノロジーなどの発展に大きく貢
献してゆくことが期待される. 特に, 超短パルスコヒー レントX線のマイクロビーム化, X線顕微鏡技術あるい は，干渉計測技術による空間分解能の飛躍的向上が実現 できれば，非常な微小領域に対して，高時間分解能で局 在化した原子・分子の動きを追跡可能になるので，一層 の付加価值実現が期待できる.

\section{謝 辞}

本稿で紹介したNTT物性科学基礎研究所の時間分解X 線吸収分光研究は, 西川正主幹研究員, 小栗克弥主任 研究員, ならびに岡野泰涁氏(現在, 分子科学研究所) によって, 一部, 科学研究費助成金特定領域研究「強 レーザー光子場における分子制御」の支援を受け，遂行 されたものである。また， $\mathrm{ZnO}$ の成果に関しては, 山ノ井航平氏, 酒井浩平氏, 中里智治研究員 (以上大 阪大学), Dirk Ehrentraut准教授, 福田承夫教授 (以上東 北大学), 永園 充チームリーダー, 富樫格研究員, 松原伸一研究員, 登野健介研究員, 東谷篤志研究員, 矢橋牧名チームリーダー, 木村洋昭主幹研究員, 大橋治彦グループリーダー, 石川哲也プロジェクト リーダー(以上SPring- 8/XFEL (理研及び高輝度光科学研 究センター))によって遂行され, サンプル作成において (株) 福田結晶技術研究所の協力を受け, FEL光源の利用 に関しては理化学研究所のSCSS試験加速器運転グルー プ・利用グループの支援を受けた。ここに関係各位に感 謝の意を表する.

\section{参考文献}

1) 緑川 克美：応用物理 78 (2009) 107.

2)「アト秒科学最前線」特集号：レーザー研究 36 (2008) pp.4-30.

3) A. McPherson, G. Gibson, H. Jara, U. Johanson, T. S. Luk, I. A. McIntyre, K. Boyer, and C. K. Rhodes: J. Opt. Soc. Am. B 4 (1987) 595.

4) S. C. Wilks, W. L. Kruer, and W. B. Mori: IEEE Trans. Plasma Sci. 21 (1993) 120.

5) P. A. Norreys, M. Zepf, S. Moustaizis, A. P. Fews, J. Zhang, P. Lee, M. Bakarezos, C. N. Danson, A. Dyson, P. Gibbon, et al.: Phys. Rev. Lett. 76 (1996) 1832.

6) M. M. Murnane, H. C. Kapteyn, S. P. Gordon, and R. W. Falcone: Appl. Phys. B 58 (1994) 261.

7) J. C. Kieffer, M. Chaker, J. P. Matte, H. Péppin, C. Y. Côté, Y. Beaudoin, T. W. Johnston, C. Y. Chien, S. Coe, G. Mourou, et al.: Phys. Fluids B 5 (1993) 2676.

8) R. W. Schoenlein, S. Chattopadhyay, H. H. W. Chong, T. E. Glover, P. A. Heimann, C. V. Shank, A. A. Zholents, and M. S. Zolotorev: Science 287 (2000) 2237.

9) C. Rischel, A. Rousse, I. Uschmann, P.-A. Albouy, J.-P. Geindre, P. Audebert, J.-C. Gauthier, E. Förster, J.-L. Martin, and A. Antonetti: Nature 390 (1997) 490.

10) C. W. Siders, A. Cavalleri, K. S.-Tinten, Cs. Toth, T. Guo, M. Kammler, M. H. von Hoegen, K. R. Wilson, D. von der Linde, and C. P. J. Barty: Science 286 (1999) 1340.

11) Y. Hironaka, A. Yazaki, F. Saito, K. G. Nakamura, K. Kondo, H. Takenaka, and M. Yoshida: Appl. Phys. Lett. 77 (2000) 1967.

12) A. Rousse, C. Rischel, and J.-C. Gauthier: Rev. Mod. Phys. 73 (2001) 17.

13) K. Sokolowski-Tinten, C. Blome, J. Blums, A. Cavalleri, C. Dietrich, A. Tarasevitch, I. Uschmann, E. Förster, M. Kammler, M. Horn-von-Hoegen, et al.: Nature 422 (2003) 287. 
14) H. Kishimura, H. Morishita, Y. Okano, Y. Hironaka, K. Kondo, and K. G. Nakamura: Phys. Rev. B 74 (2006) 224301.

15) H. Kishimura, A. Yazaki, H. Kawano, Y. Hironaka, K. G. Nakamura, and K. Kondo: J. Chem. Phys. 117 (2002) 10239.

16) K. G. Nakamura, S. Ishii, S. Ishitsu, M. Shiokawa, H. Takahashi, K. Dharmalingam, J. Irisawa, Y. Hironaka, K. Ishioka, and M. Kitajima: Appl. Phys. Lett. 93 (2008) 061905.

17) M. H. Sher, U. Mohideen, H. W. K. Tom, O. R. Wood II, G. D. Aumiller, and R. R. Freeman: Opt. Lett. 18 (1993) 646.

18) F. Ráksi, K. R. Wilson, Z. Jiang, A. Ikhlef, C. Y. Côté, and J.-C. Kieffer: J. Chem. Phys. 105 (1996) 6066.

19) J. Workman, M. Nantel, A. Maksimchuk, and D. Umstadter: Appl. Phys. Lett. 70 (1997) 312.

20) H. Nakano, Y. Goto, P. Lu, T. Nishikawa, and N. Uesugi: Appl. Phys. Lett. 75 (1999) 2350.

21) H. Nakano, P. Lu, T. Nishikawa, and N. Uesugi: Proc. SPIE 4352 (2001) 175.

22) P. Forget, F. Dorchies, J.-C. Kieffer, and O. Peyrusse: Chem. Phys. 299 (2004) 259.

23) I. V. Tomov, J. Chen, X. Ding, and P. M. Rentzepis: Chem. Phys. Lett. 389 (2004) 363.

24) T. Lee, Y. Jiang, and C. G. Rose-Petruck: J. Chem. Phys. 122 (2005) 084506.

25) K. Oguri, Y. Okano, T. Nishikawa, and H. Nakano: Appl. Phys. Lett. 87 (2005) 011503.

26) Y. Okano, K. Oguri, T. Nishikawa, and H. Nakano: Rev. Sci. Instrum. 77 (2006) 046105.

27) Y. Okano, K. Oguri, T. Nishikawa, and H. Nakano: Appl. Phys. Lett. 89 (2006) 221502.

28) E. Seres, J. Seres, and C. Spielmann: Appl. Phys. Lett. 89 (2006) 181919.

29) E. Seres and C. Spielmann: Appl. Phys. Lett. 91 (2007) 121919.

30) K. Oguri, Y. Okano, T. Nishikawa, and H. Nakano: Phys. Rev. Lett. 99 (2007) 165003.

31) K. Oguri, Y. Okano, T. Nishikawa, and H. Nakano: Phys. Rev. B 79 (2009) 144106.

32) M. Bauer, C. Lei, K. Read, R. Tobey, J. Gland, M. M. Murnane, and H. C. Kapteyn: Phys. Rev. Lett. 87 (2001) 025501.

33) P. Siffalovic, M. Drescher, M. Spieweck, T. Wiesenthal, Y. C. Lim, R. Weidner, A. Elizarov, and U. Heinzmann: Rev. Sci. Instrum. 72 (2001) 30.

34) L. N.-Glandorf, M. Scheer, D. A. Samuels, A. M. Mulhisen, E. R. Grant, X. Yang, V. M. Bierbaum, and S. R. Leone: Phys. Rev. Lett. 87 (2001) 193002.

35) L. N.-Glandorf, M. Scheer, D. A. Samuels, V. Bierbaum, and S. R. Leone: Rev. Sci. Instrum. 73 (2002) 1875

36) M. Drescher, M. Hentschel, R. Kienberger, M. Uiberacker, V. Yakovlev, A. Scrinzi, Th. Westerwalbesloh, U. Kleineberg, U. Heinzmann, and F. Krausz: Nature 419 (2002) 803.

37) T. Kawachi, M. Kado, M. Tanaka, A. Sasaki, N. Hasegawa, A. V. Kilpio, S. Namba, K. Nagashima, P. Lu, K. Takahashi, et al.: Phys. Rev. A 66 (2002) 033815.

38) Y. Ochi, T. Kawachi, N. Hasegawa, M. Nishikino, T. Ohba, M. Tanaka, M. Kishimoto, T. Kaihori, K. Nagashima, and A. Sugiyama: Jpn. J. Appl. Phys. 48 (2009) 120212.

39) M. Kishimoto, K. Namikawa, K. Sukegawa, H. Yamatani, N. Hasegawa, and M. Tanaka: Rev. Sci. Instrum. 81 (2010) 013905.

40) K. Namikawa, M. Kishimoto, K. Nasu, E. Matsushita, R. Z. Tai, K. Sukegawa, H. Yamatani, H. Hasegawa, M. Nishikino, M. Tanaka, et al.: Phys. Rev. Lett. 103 (2009) 197401.

41) T. Shintake, H. Tanaka, T. Hara, T. Tanaka, K. Togawa, M. Yabashi, Y. Otake, Y. Asano, T. Bizen, T. Fukui, et al.: Nature Photonics 2 (2008) 555.

42) T. Sato, T. Okino, K. Yamanouchi, A. Yagishita, F. Kannari, K. Yamakawa, K. Midorikawa, H. Nakano, M. Yabashi, M. Nagasono, et al.: Appl. Phys. Lett. 92 (2008) 154103.

43）佐藤克洋, 岩崎純史, 沖野友哉, 山内薰, 柳下明, 矢澤洋紀，神成文彦，青山誠，山川考一，緑川克美， 他：レーザー研究 37 (2009) 905.

44) H. Fukuzawa, K. Motomura, X.-J. Liu, G. Prümper, M. Okunishi, K. Ueda, N. Saito, H. Iwayama, K. Nagaya, M. Yao, et al.: J. Phys. B: At. Mol. Opt. Phys. 42 (2009) 181001.

45) S. Y. Liu, Y. Ogi, T. Fuji, K. Nishizawa, T. Horio, T. Mizuno, H. Kohguchi, M. Nagasono, T. Togashi, K. Tono, et al.: Phys. Rev.
A 81 (2010) 031403(R).

46) H. Iwayama, K. Nagaya, M. Yao, H. Fukuzawa, X.-J.Liu, G. Prümper, M. Okunishi, K. Shimada, K. Ueda, T. Harada, et al.: J. Phys. B: At. Mol. Opt. Phys. 42 (2009) 134019.

47) K. Motomura, H. Fukuzawa, L. Foucar, X.-J. Liu, G. Prümper, K. Ueda, N. Saito, H. Iwayama, K. Nagaya, H. Murakami, et al.: J. Phys. B: At. Mol. Opt. Phys. 42 (2009) 221003.

48) Y. Inubushi, H. Yoneda, A. Higashiya, T. Ishikawa, H. Kimura, T. Kumagai, S. Morimoto, M. Nagasono, H. Ohashi, F. Sato, et al.: Rev. Sci. Instrum. 81 (2010) 036101.

49) A. Paulus, C. Winterfeldt, T. Pfeifer, D. Walter, G. Gerber, and C. Spielmann: Rev. Sci. Instrum. 77 (2006) 043105.

50) A. L. Cavalieri, N. Müller, Th. Uphues, V. S. Yakovlev, A. Baltuška, B. Horvath, B. Schmidt, L. Blümel, R. Holzwarth, S. Hendel, et al.: Nature 449 (2007) 1029.

51) L. Miaja-Avila, G. Saathoff, S. Mathias, J. Yin, C. La-o-vorakiat, M. Bauer, M. Aeschlimann, M. M. Murnane, and H. C. Kapteyn: Phys. Rev. Lett. 101 (2008) 46101.

52) S. L. Johnson, P. Beaud, C. J. Milne, F. S. Krasniqi, E. S. Zijlstra, M. E. Garcia, M. Kaiser, D. Grolimund, R. Abela, and G. Ingold: Phys. Rev. Lett. 100 (2008) 155501.

53）宇田川 康夫編：「X線吸収微細構造 - XAFSの計測と解析」, 学会出版センター (1993).

54）太田俊明編：「X線吸収分光法 $-X A F S$ と定用 -」, ア イピーシー (2002)

55) B. Yaakobi, H. Deckman, P. Bourke, S. Letzring, and J. M. Soures: Appl. Phys. Lett. 37 (1980) 767.

56) P. J. Mallozzi, R. E. Schwertzel, H. M. Eaptein, and B. E. Campbell: Phys. Rev. A 23 (1981) 824.

57) R. W. Eason, B. K. Bradley, J. D. Kilenny, and G. N. Greaves: J. Phys. C: Solid State Phys. 17 (1984) 5067.

58) K. Murakami, H. C. Gerritsen, H. van Brug, F. Bijkerk, F. W. Saris, and M. J. van der Wiel: Phys. Rev. Lett. 56 (1986) 655.

59) B. K. Bradley, J. Kilkenny, S. J. Rose, and J. D. Hares: Phys. Rev. Lett. 59 (1987) 2995.

60) J. Balmer, C. L. S. Lewis, R. E. Corbett, E. Robertson, S Saadat, D. O'Neil, J. D. Kilkeny, C. A. Back, and R. W. Lee: Phys. Rev. A 40 (1989) 330.

61) A. Klisnick, C. Chenais-Popovics, C. A. Back, P. Zeitoun, P. Renaudin, O. Rancu, J. C. Gauthier, and P. Jaegle: Phys. Rev. E 53 (1996) 5315.

62) M. Fajardo, P. Audebert, P. Renaudin, H. Yashiro, R. Shepherd, J. C. Gauthier, and C. Chenais-Popovics: Phys. Rev. Lett. 86 (2001) 1231.

63) P. Audebert, P. Renaudin, S. Bastiani-Ceccotti, J.-P. Geindre, C. Chenais-Popovics, S. Tzortzakis, V. Nagels-Silvert, R. Shepherd, I. Matsushima, S. Gary, et al.: Phys. Rev. Lett. 94 (2005) 025004.

64) B. W. Adams, M. F. DeCamp, E. M. Dufresne, and D. A. Reis: Rev. Sci. Instrum. 73 (2002) 4150.

65) T. Lee, F. Benesch, Y. Jiang, and C. Rose-Petruc: Chem. Phys. 299 (2004) 233.

66) B. Yaakobi, F. J. Marshall, T. R. Boehly, R. P. J. Town, and D. D. Meyerhofer: J. Opt. Soc. Am. B 20 (2002) 238.

67) B. Yaakobi, D. D. Meyerhofer, T. R. Boehly J. J. Rehr, B. A. Remington, P. G. Allen, S. M. Polla, and R. C. Albers: Phys. Rev. Lett. 92 (2005) 095504.

68) B. Yaakobi, T. R. Boehly, D. D. Meyerhofer, T. J. B. Collins, B. A. Remington, P. G. Allen, S. M. Pollaine, H. E. Lorenzana, and J. H. Eggert: Phys. Rev. Lett. 95 (2005) 075501.

69) A. Cavalleri, M. Rini, H. H. W. Chong, S. Fourmaux, T. E. Glover, P. A. Heimann, J. C. Kieffer, and R. W. Schoenlein: Phys. Rev. Lett. 95 (2005) 067405.

70) S. L. Johnson, P. A. Heimann, A. M. Lindenberg, H. O. Jeschke, M. E. Garcia, Z. Chang, R. W. Lee, J. J. Rehr, and R. W. Falcone: Phys. Rev. Lett. 91 (2003) 157403.

71) C. V. Shank, R. Yen, and C. Hirlimann: Phys. Rev. Lett. 51 (1983) 900.

72) A. Rousse, C. Rischel, S. Fourmaux, I. Uschmann, S. Sebban, G. Grillon, Ph. Balcou, E. Förster, J. P. Geindre, P. Audebert, et al.: Nature 410 (2001) 65.

73) K. Eidmann and T. Kishimoto: Appl. Phys. Lett. 49 (1986) 377.

74) G. M. Zeng, H. Daido, K. Murai, Y. Kato, M. Nakatsuka, and S. Nakai: J. Appl. Phys. 72 (1992) 3355. 
75) S. Eliezer, N. Eliaz, E. Grossman, D. Fisher, I. Gouzman, Z. Henis, S. Pecker, Y. Horovitz, M. Fraenkel, S. Maman, et al.: Phys. Rev. B 69 (2004) 144119.

76) S. Amoruso, R. Bruzzese, N. Spinelli, R. Velotta, M. Vitiello, X. Wang, G. Ausanio, V. Iannotti, and L. Lanotte: Appl. Phys. Lett. 84 (2004) 4502.

77) F. Qian, R. K. Singh, S. K. Dutta, and P. P. Pronko: Appl. Phys. Lett. 67 (1995) 3120

78) M. Okoshi, S. Higuchi, and M. Hanabusa: J. Appl. Phys. 86 (1999) 1768

79) J. Perrier̀e, E. Millona, W. Seiler, V. Craciun, O. Albert, J. C. Loulergue, and J. Etchepare: J. Appl. Phys. 91 (2002) 690.

80) T. Ohyanagi, A. Miyashita, K. Murakami, and O. Yoda: Jpn. J. Appl. Phys. 33 (1994) 2586.

81) H. Nakano, K. Oguri, and T. Nishikawa: Proc. 2001 Annual Meeting of the IEEE Lasers and Electro-Optics Society (IEEE, Piscataway, NJ, 2001) p.525.

82) 中野秀俊, 小栗克弥, 岡野泰涁, 西川正：レーザー研 究 37 (2009) 886 .

83) D. Kühlke, U. Herpers, and D. von der Linde: Appl. Phys. Lett. 50 (1989) 1785.

84) H. Nakano, T. Nishikawa, H. Ahn, and N. Uesugi: Appl. Phys. Lett. 69 (1996) 2992.

$85)$ Y. Okano, H. Kishimura, Y. Hironaka, K. G. Nakamura, and K. Kondo: Appl. Surf. Sci. 197-198 (2002) 281.

86) K. Oguri, Y. Okano, T. Nishikawa, and H. Nakano: Proc. 2006 Annual Meeting of the IEEE Lasers and Electro-Optics Society (IEEE, Piscataway, NJ, 2006) p.891.

87) D. Perez and L. J. Lewis: Phys. Rev. B 67 (2003) 184102.

88) P. Lorazo, L. J. Lewis, and M. Meunier: Phys. Rev. B 73 (2006) 134108.

89) 小栗克弥, 岡野泰涁, 西川正, 中野秀俊：レーザー研 究 35 (2007) 720

90) Y. Kobayashi, O. Yoshihara, Y. Nabekawa, K. Kondo, and S. Watanabe: Opt. Lett. 21 (1996) 417.

91) K. Oguri, H. Nakano, T. Nishikawa, and N. Uesugi: Appl. Phys. Lett. 79 (2001) 4506

92) K. Oguri, T. Ozaki, T. Nishikawa, and H. Nakano: Appl. Phys. B
78 (2004) 157.

93) K. Oguri, T. Nishikawa, T. Ozaki, and H. Nakano: Opt. Lett. 29 (2004) 1279.

94) E. Ohshima, H. Ogino, I. Niikura, K. Maeda, M. Sato, M. Ito, and T. Fukuda: J. Cryst. Growth 260 (2004) 166.

95) M. Tanaka, M. Nishikino, H. Yamatani, K. Nagashima, T. Kimura, Y. Furukawa, H. Murakami, S. Saito, N. Sarukura, H. Nishimura, et al.: Appl. Phys. Lett. 91 (2007) 231117.

96) T. Nakazato, T. Shimizu, K. Yamanoi, S. Takatori, E. Estacio, M. Cadatal, N. Sarukura, H. Nishimura, K. Mima, M. Tanaka, et al.: Conference on Lasers and Electro Optics/International Quantum Electronics Conference 2009 (CLEO/IQEC 2009), JThE38, Baltimore, MD, USA, May 31- June 5, 2009.

97) H. Mimura, S. Morita, T. Kimura, D. Yamakawa, W. Lin, Y. Uehara, S. Matsuyama, H. Yumoto, H. Ohashi, K. Tamasaku, et al.: Rev. Sci. Instrum. 79 (2008) 083104.

98) T. Shimizu, K. Yamamoi, E. Estacio, T. Nakazato, K. Sakai, N. Sarukur, D. Ehrentraut, T. Fukuda, M. Nagasono, T. Togashi, et al.: Rev. Sci. Instrum. 81 (2010) 033102.

99) T. Shimizu, K. Yamanoi, T. Nakazato, K. Sakai, N. Sarukura, D. Ehrentraut, T. Fukuda, M. Nagasono, T. Togashi, S. Matsubara, et al.: 17th International Conference on Ultrafast Phenomena (UP), WC3, Snowmass, CO, USA, July 18 23, 2010.

100) D. G. Lee, J.-H. Kim, K.-H. Hong, and C. H. Nam: Phys. Rev. Lett. 87 (2001) 243902.

101) Y. Oishi, M. Kaku, A. Suda, F. Kannari, and K. Midorikawa: Opt. Express 14 (2006) 7230.

102) C. Altucci, R. Bruzzese, C. de Lisio, M. Nisoli, S. Stagira, S. De Silvestri, O. Svelto, A. Boscolo, P. Ceccherini, L. Poletto, et al.: Phys. Rev. A 61 (1999) 021801(R).

103) H. T. Kim, D. G. Lee, K.-H. Hong, J.-H. Kim, I. W. Choi, and C. H. Nam: Phys. Rev. A 67 (2003) 051801(R).

104) P. Salières, L. Le Déroff, T. Auguste, P. Monot, P. d'Oliveira, D. Campo, J.-F. Hergott, H. Merdji, and B. Carré: Phys. Rev. Lett. 83 (1999) 5483.

105) D. Descamps, C. Lyngä, J. Norin, A. L'Huillier, C.-G. Wahlström, J.-F. Hergott, H. Merdji, P. Salières, M. Bellini, and T. W. Hänsch: Opt. Lett. 25 (2000) 135.
ポンププローブ分光 (pump-probe spectroscopy)

ポンプ光を試料に照射することによって，試料中に誘 導される応答特性の変化をプローブ光で検出するタイプ の分光手法である. ポンプ光，プローブ光ともに短パル スにしておき, ポンプ光パルスとプローブ光パルスとの 試料への到着時刻を可変にすることによって, ポンプ光 パルスで過渡的に誘導された試料の応答特性変化の時間 発展を調べることができる。このとき，時間分解能は， プローブ光のパルス幅, 検出器の応答速度のいずれかで 決まると考えられる。しかし，その前提として，試料面 (内部)において，ポンプ光パルスとプローブ光パルスと
が高精度に同期しており，また，双方が空間的に一致し ていることが必要である。このような要請を満たすため の光学調整を高い信頼性で実現するための実時間モ二夕 は，実験装置の組み立て，評価用のツールとしても有用 である。本論文で紹介したポンププローブ型の時間分解 分光とは, 構造解析に使用するX線 (プローブ)を短パル ス化することによって，ポンプ光照射によって誘導され る物質の過渡的な構造変化の時間発展追跡を可能にしよ うとするものである。 